\title{
A radiocarbon chronology for the aceramic shell-middens of coastal Oman
}

\section{PAOLO BIAGI}

Dipartimento di Scienze Storico-Archeologiche e Orientalistiche, University of Venice, Italy

Our knowledge of the prehistory of coastal Oman has greatly increased during the last ten years. This article considers the radiocarbon chronology of the aceramic shell-middens scattered along the coast between Muscat, to the north, and Shuwayr, to the south. The appearance of these middens seems to correspond to the climatic deterioration that, according to more recent results, took place around the middle of the seventh millennium BP. The number of sites seems to have increased since the beginning of the actual arid phase, around $6000 \mathrm{BP}$.

\section{Preface}

Until 1977 no radiocarbon dates were available for the coastal Omani shell-middens. The first set of dates was obtained from a few charcoal samples collected from the surface and during rescue excavation at two sites on the cape of Ra's al-Hamra, west of the Capital, Muscat (1). During the 1980's the $14 \mathrm{C}$ dates were mainly obtained from samples collected during the excavations carried out at RH5, RH6 and RH10 (2), as well as from several sites discovered along the coast between Ra's Suwadi, to the north, and the Dhofar border (3).

\section{C chronology of the shell-middens of Ra's al-Hamra}

On the Cape of Ra's al-Hamra (Fig. I), only three sites have been accurately investigated, namely RH5, RH6 and RH10. RH5 was excavated between 1980 and 1985. Its stratigraphy, some I metre thick, has been interpreted with seven main phases of occupation (4). The uppermost layer 0 , partly eroded by natural agents, gave only a few rubbish pits. One of these, Pit HWE/B, yielded many sherds of one black burnished pot (5). This phase has been dated to $4760 \pm 100$ BP: 3670 (3542) 3390 cal BC (Bln-3140) and to $4949 \pm 60$ BP: 3794 (3717) $3679 \mathrm{cal} \mathrm{BC} \mathrm{(Bln-3401)} \mathrm{(6).} \mathrm{The} \mathrm{dating}$ of the first occupation has been obtained from charcoal of Avicennia marina from a fireplace dug into the rubified bedrock discovered in the south-eastern corner of the site: $5510 \pm 60$ BP: 4406 (4360) 4338 cal BC (Bln-3149).

A graveyard of 220 individuals dated between $4920 \pm 60$ BP: 3785 (3706) $3659 \mathrm{cal}$ BC (Bln-3156) and 4740 \pm 60 BP: 3633 (3522) 3387 cal BC (Bln-2737), was uncovered in the north-eastern part of the midden (7) (Table 1 ).

On the same cape, a few metres to the north-west of RH5 lay the site of RH10. According to the excavators, it was inhabited in two different periods dated to the first half of the seventh millennium and to the fourth millennium BP, while a cemetery with 26 burials should be attributed to $c a .5000 \mathrm{BP}$ (8) (Table 2).

Extremely important results were produced from the excavation of RH6, on the right bank of Wadi Aday in the Qurm National Reserve 


\begin{tabular}{|c|c|c|c|c|}
\hline Site & Layer & Feature & Lab n ${ }^{\circ}$ & BP date \\
\hline RH5 & 0 & Pit HXF & Bln-3140 & $4760 \pm$ \\
\hline RH5 & 0 & Pit HXP-B & Bln-3401 & $4940 \pm$ \\
\hline RH5 & 1 & Hearth HOH-D & Bln-3153 & $4730 \pm$ \\
\hline RH5 & 1 & Hearth HOH-D & $B \ln -3153 \mathrm{~A}$ & $4770 \pm$ \\
\hline RH5 & 1 & Pit HWT-CD & Bln-3168 & $4840 \pm$ \\
\hline RH5 & 1 & Sq. HWJ-AB & Bln-3143 & $4880 \pm$ \\
\hline RH5 & 1 & Pit HWN-D & Bln-3144 & $4900 \pm$ \\
\hline RH5 & 1 & Pit HWM-D & Bln-3141 & \\
\hline RH5 & 2 & Sq. HWO-AB & & $4820 \pm$ \\
\hline RH5 & 2 & Hearth HOF-D & Bln-3154 & $4870 \pm$ \\
\hline RH5 & 2 & Pit HXS & Bln-3148 & \\
\hline RH5 & 3 & Sq. HXG-AB & & \\
\hline RH5 & 3 & Pit HXP-C & Bln-3402 & $4900 \pm$ \\
\hline RH5 & 3 & Heart HOF-BC & Bln-3155 & $4910 \pm$ \\
\hline RH5 & $3 a$ & Sq. HXG-AB & & \\
\hline RH5 & $3 b$ & Sq. HXG-CD & Bln-3147 & \\
\hline RH5 & $3 \mathrm{~d}$ & Hearth HWI & Hv-13198 & $4768 \pm$ \\
\hline RH5 & $3 d$ & & & \\
\hline RH5 & 4 & Sq. HWO-AB & Bln-3399 & \\
\hline RH5 & 4 & Sq. HXQ-CD & OxA-2931 & $5160 \pm$ \\
\hline RH5 & 4 & & & $5090 \pm$ \\
\hline RH5 & 4 & Sq. HWJ-BC & Bln-3394/II & $5200 \pm$ \\
\hline RH5 & 4 & Sq. HWJ-BC & Bln-3393/I & $5190 \pm$ \\
\hline RH5 & 4 & Sq. HWJ-BC & Bln-3393/II & $5200 \pm$ \\
\hline RH5 & 5 & Hearth HXQ-B & Bln-3400 & \\
\hline RH5 & $5 a$ & Sq. HWO-AB & Bln-3404 & $4990 \pm$ \\
\hline RH5 & $5 a$ & Pit HWO & Bln-3406 & $5050 \pm$ \\
\hline RH5 & $5 a$ & Hearth HXQ & Bln-3405 & \\
\hline RH5 & $5 b$ & Sq. HXL-BC & Bln-3407 & $4860 \pm$ \\
\hline RH5 & $5 b$ & Hearth 2 & Bln-3149 & $5480 \pm$ \\
\hline RH5 & $3 \mathrm{~d} ?$ & Fishpit 12 & Hv-13193 & $5120 \pm$ \\
\hline RH5 & $3 \mathrm{~d} ?$ & Fishpit 16 & Hv-13194 & $5181 \pm$ \\
\hline RH5 & & Sq. HEV-B & Bln-2736 & $4650 \pm$ \\
\hline RH5 & & Hearth HPF-CD & Bln-3152 & $4900 \pm$ \\
\hline RH5 & & Sq. KDS-AD & $B \ln -2735$ & $5010 \pm$ \\
\hline RH5 & & Sq. HON-C & $\mathrm{Hv}-10925$ & $5395 \pm$ \\
\hline $\mathrm{RH}^{*}$ & Top & Sq. HJP & Bln-3397 & $5900 \pm$ \\
\hline
\end{tabular}

cal BC date ( $(1 \sigma)$

3670 (3542) 3390 unknown mainly Avicennia marina unknown mainly Avicennia marina

unknown mainly Avicennia marina $3628(3518) 3383$ $3646(3617,3581,3537) 3507$ 3699 (3648) 3541 3719 (3684) 3638 3772 (3697) 3650 3954 (3805) 3778 3690 (3639) 3528 3713 (3672) 3633 3918 (3788) 3714 3637 (3526) 3391 3776 (3697) 3646 3777 (3701) 3659 3667 (3631) 3520 $3785(3706) 3659$ 3675 (3550) 3426 known mainly Avicennia marina unknown mainly Avicennia marina unknown mainly Avicennia marina unknown mainly Avicennia marina unknown mainly Avicennia marina unknown mainly Avicennia marina unknown mainly Avicennia marina unknown mainly Avicennia marina unknown mainly Avicennia marina unknown mainly Avicennia marina unknown mainly Avicennia marina unknown mainly Avicennia marina -20.8 mainly Avicennia marina 3968, $(3939,3858,3828) 3800$ unknown mainly Avicennia marina 4000 (3972) 3827 $4041(3988) 3862$

$4001(3984) 3964$ unknown mainly Avicennia marina $-26.9 \quad$ Setaria sp.

+1.6 Anadara uropigimelana

4028 (4001) 3983

3982 (3952) 3804 $3918(3788) 3714$ $3963(3924,3875,3815) 3787$ 3992 (3962) 3814 $3704(3663) 3633$ 4371 (4350) 4321 4011 (3969) 3826 4050 (4002) 3959 $3506(3378) 3358$ 3776 (3697) 3646 3951 (3807) 3702 $4344(4253) 4166$ 4877 (4802) 4734 unknown Terebralia palustris

unknown Avicennia marina

unknown mainly Avicennia marina unknown mainly Avicennia marina unknown mainly Avicennia marina unknown mainly Avicennia marina unknown mainly Avicennia marina $-23.8 \quad$ Ashy sediments

$-23.8 \quad$ Ashy sediments unknown Charcoal unknown Charcoal unknown

$-16.2$

unknown

\section{Charcoal}

Ashy sediments

Fish bones and ashy sediments
References

Isetti \& Biagi 1989: 6

Isetti \& Biagi 1989: 6

Salvatori pers. comm. 1991

Salvatori pers. comm. 1991 Isetti \& Biagi 1989: 6 Isetti \& Biagi 1989: 6 Isetti \& Biagi 1989: 6 Isetti \& Biagi 1989: 6 Isetti \& Biagi 1989: 6

Salvatori pers. comm. 1991

Salvatori pers. comm. 1991 Isetti \& Biagi 1989: 6 Isetti \& Biagi 1989: 6 Salvatori pers. comm. 1991 Isetti \& Biagi 1989: 6 Isetti \& Biagi 1989: 6 Isetti \& Biagi 1989: 6 Isetti \& Biagi 1989: 6 Unpublished

Biagi \& Nisbet in press Isetti \& Biagi 1989: 6

Isetti \& Biagi 1989: 6

Biagi \& Nisbet in press Isetti \& Biagi 1989: 6 Isetti \& Biagi 1989: 6 Isetti \& Biagi 1989: 6 Isetti \& Biagi 1989: 6 Isetti \& Biagi 1989: 5

Uerpmann n.d.

Uerpmann n.d.

Salvatori pers. comm. 1991 Salvatori pers. comm. 1991 Salvatori pers. comm. 1991 Salvatori pers. comm. 1991 Unpublished 


\begin{tabular}{|c|c|c|c|c|c|c|c|c|}
\hline $\mathrm{RH}^{*}{ }^{*}$ & Middle & $\mathrm{Sq} . \mathrm{HJP}$ & Bln-3395 & $6060 \pm 60$ & 5068 (4961) 4910 & unknown & Ashy sediments & Unpublished \\
\hline $\mathrm{RH}^{*}{ }^{*}$ & Bottom & Sq. HJP & Bln-3396 & $6080 \pm 60$ & $5133(5006) 4925$ & unknown & Fish bones & Unpublished \\
\hline RH5 & & Grave 21 & Bln-2737 & $4740 \pm 60$ & $3633(3522) 3387$ & unknown & Charcoal & Isetti \& Biagi 1989: 5 \\
\hline RH5 & & Grave 60 & $B \ln -3150$ & $4750 \pm 60$ & $3637(3526) 3391$ & unknown & Charcoal & Salvatori pers. comm. 1991 \\
\hline RH5 & & Grave 84 & $B \ln -3151$ & $4760 \pm 60$ & $3641(3612,3588,3531) 3405$ & unknown & Charcoal & Salvatori pers. comm. 1991 \\
\hline RH5 & & Grave 69 & Bln-3157 & $4840 \pm 60$ & $3699(3648) 3541$ & unknown & Charcoal & Salvatori pers. comm. 1991 \\
\hline RH5 & & Grave 60 & $B \ln -3150 A$ & $4850 \pm 60$ & $3703(3654) 3548$ & unknown & Charcoal & Salvatori pers. comm. 1991 \\
\hline RH5 & & Grave 19 & Bln-2738 & $4860 \pm 60$ & $3708(3663) 3629$ & unknown & Charcoal & Salvatori pers, comm. 1991 \\
\hline RH5 & & Grave 215 & Bln-3156 & $4920 \pm 60$ & $3785(3706) 3659$ & unknown & Charcoal & Isetti \& Biagi 1989: 5 \\
\hline
\end{tabular}

The dates marked with an asterisk $\left({ }^{*}\right)$ are not accepted by the present Author.

The dates obtained from charcoal are most probably from Avicennia marina.

Table 2

\begin{tabular}{|c|c|c|c|c|c|c|c|c|}
\hline Site & Layer & Feature & Lab n ${ }^{\circ}$ & BP date & cal BC date $(1 \sigma)$ & $\delta 13 \mathrm{C}$ & Material & References \\
\hline Qurm N & Surf. & & $\mathrm{Hv}-14212$ & $5229 \pm 160$ & $4270(4042) 3860$ & -2.7 & Shells & Uerpmann 1992: 341 \\
\hline $\mathrm{RH}^{*}$ & Deposit & & $\mathrm{Hv}-12976$ & $2508 \pm 95$ & $806(766) 445$ & -22.9 & Ashy sediments & Uerpmann 1992: 337 \\
\hline RHI & Surf. & & Hv-12977 & $4571 \pm 105$ & $3410(3348) 3100$ & -3.1 & Shells & Uerpmann 1992: 337 \\
\hline $\mathrm{RH} 3$ & Surf. & & P-2673 & $4030 \pm 70$ & $2639(2572,2565,2547) 2489$ & unknown & Charcoal & Biagi et al. 1984: 57 \\
\hline $\mathrm{RH} 3$ & Surf. & & P-2738 & $4170 \pm 220$ & $3010(2780) 2480$ & unknown & Charcoal & Biagi et al. 1984: 57 \\
\hline RH4 & $20 \mathrm{cms}$ & & P-2741 & $4050 \pm 50$ & $2610(2578) 2488$ & +3.73 & Charcoal & Meulengracht et al. 1981: 233 \\
\hline RH4 & $30 \mathrm{cms}$ & & P-2740 & $4320 \pm 200$ & $3210(2956) 2680$ & unknown & Charcoal & Meulengracht et al. 1981: 233 \\
\hline $\mathrm{RH} 4$ & 2 & Grave 11 & P-2739 & $5140 \pm 200$ & $4180(3984) 3740$ & unknown & Charcoal & Meulengracht et al. 1981: 233 \\
\hline RH7 & Surf. & & Hv-10926 & $6876 \pm 105$ & $5840(5733) 5640$ & -1.2 & Arcidae & Uerpmann 1992: 341 \\
\hline RH10* & & Grave 105 & Bln-2740 & $1810 \pm 50$ & $126(215) 247 \mathrm{AD}$ & unknown & Charcoal & Unpublished \\
\hline RH10* & 1 & Sq. EAF-EAM & Bln-2741 & $2050 \pm 50$ & $125(77) 4$ & unknown & Charcoal & Unpublished \\
\hline RHIO & 1 & Sq. EAG & Bln-2739 & $3550 \pm 60$ & 1975 (1903) 1800 & unknown & Charcoal & Biagi et al. 1984: 57 \\
\hline RH10 & 1 & Grave fill & $\mathrm{Hv}-10003$ & $3866 \pm 90$ & $2486(2360) 2210$ & -22.9 & Ashy sediments & Biagi et al. 1984: 57 \\
\hline RH10 & & Sq. DJO-B & $\mathrm{Hv}-13197$ & $4451 \pm 90$ & $3334(3088) 2947$ & -18.2 & Charcoal & Uerpmann n.d. \\
\hline RHiO & & Grave 121 & $\mathrm{Hv}-10004$ & $5121 \pm 65$ & $3998(3967) 3818$ & -18.2 & Ashy sediments & Biagi et al. 1984: 57 \\
\hline RH10 & 2 & Sq. DDJ & $\mathrm{Hv}-10002$ & $6550 \pm 100$ & $5550(5487) 5370$ & +0.3 & Ostridae & Biagi et al. 1984: 57 \\
\hline RH10 & 3 & Sq. DDJ & $\mathrm{Hv}-10001$ & $6713 \pm 105$ & $5680(5604) 5510$ & -0.2 & Shells & Biagi et al. 1984: 57 \\
\hline RH10 & & & Hv-13199 & $6443 \pm 105$ & $5490(5376) 5280$ & +0.5 & Shells & Uerpmann 1992: 341 \\
\hline RH12 & Surf. & & $\mathrm{Hv}-13743$ & $5776 \pm 100$ & 4780 (4684) 4520 & -1.8 & Shells & Uerpmann 1992: 341 \\
\hline
\end{tabular}

The dates marked with an asterisk $\left(^{*}\right)$ are not accepted by the present Author

The dates obtained from charcoal are most probably from Avicennia marina. 
Table 3

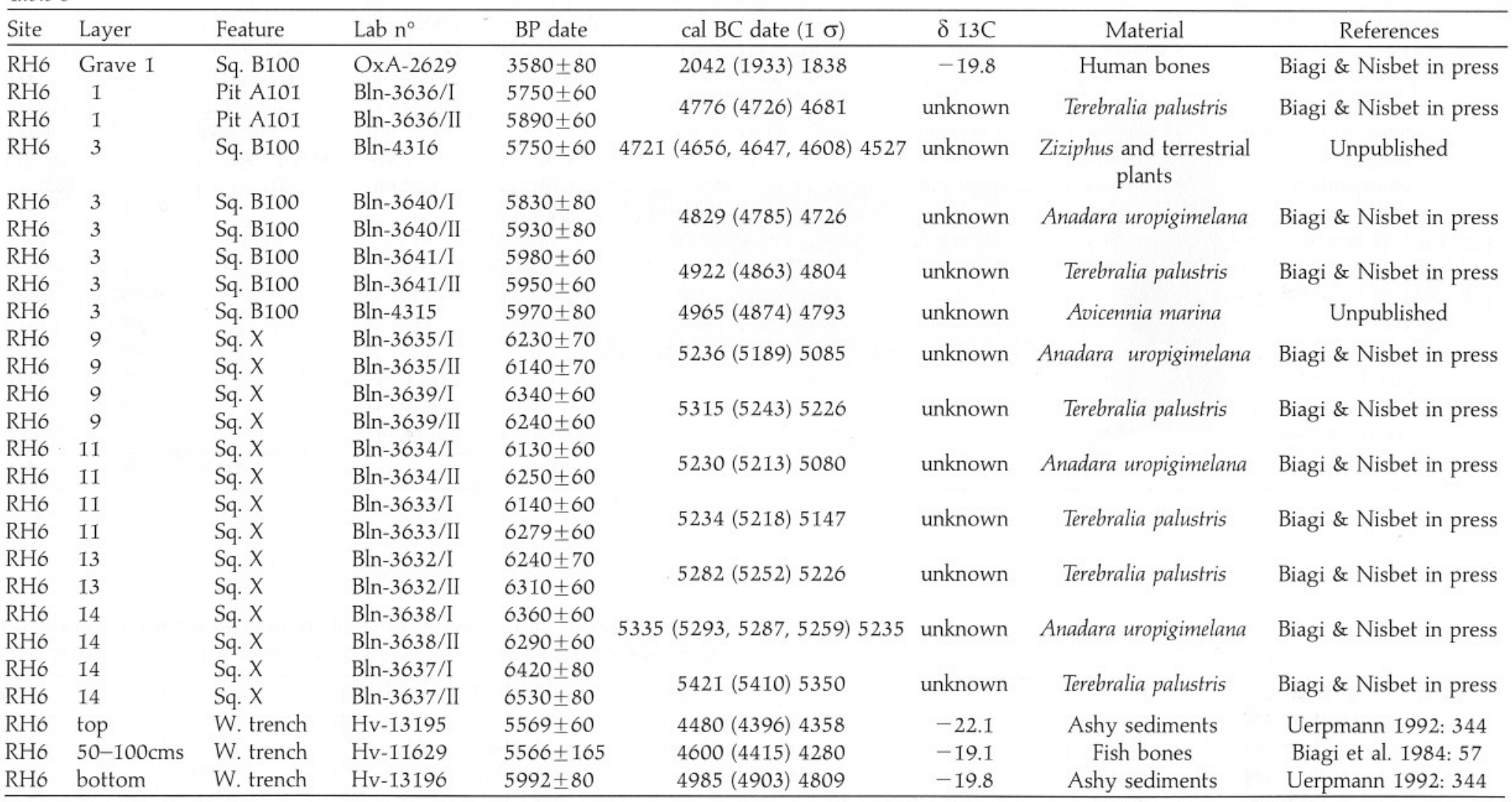



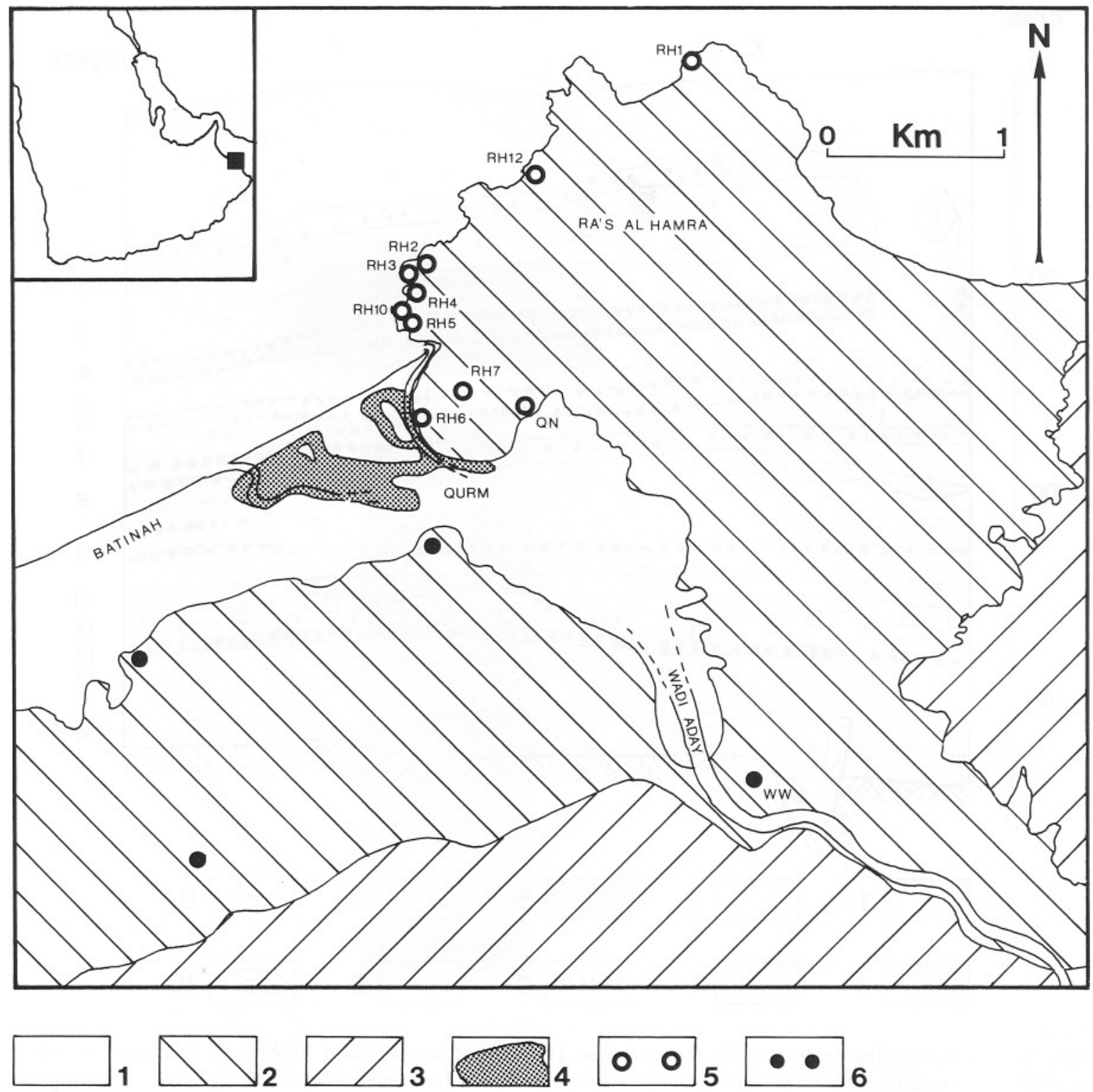

Fig. 1.

Radiocarbon sample archaeological sites along the coast of Ra's al-Hamra and Qurm. 1) Lowland zone. 2) Foothills. 3) Mountain zone. 4) Mangrove swamp. 5) 14C dated shell-middens. 6) Other sites in the area (Drawn by P. Biagi).

(9). This shell-mound was test-trenched for the first time in 1977. The excavations were later resumed in 1986 and 1988, revealing a very detailed sequence from which several $14 \mathrm{C}$ dates have been obtained (Table 3). In 1986, two trenches were opened, one along the western slope (Fig. 2), the second on the uppermost part of the site. The series discovered along the western slope was composed of fourteen layers that started to form towards the second half of the seventh millennium BP (10). The upper trench was interrupted when 
cms

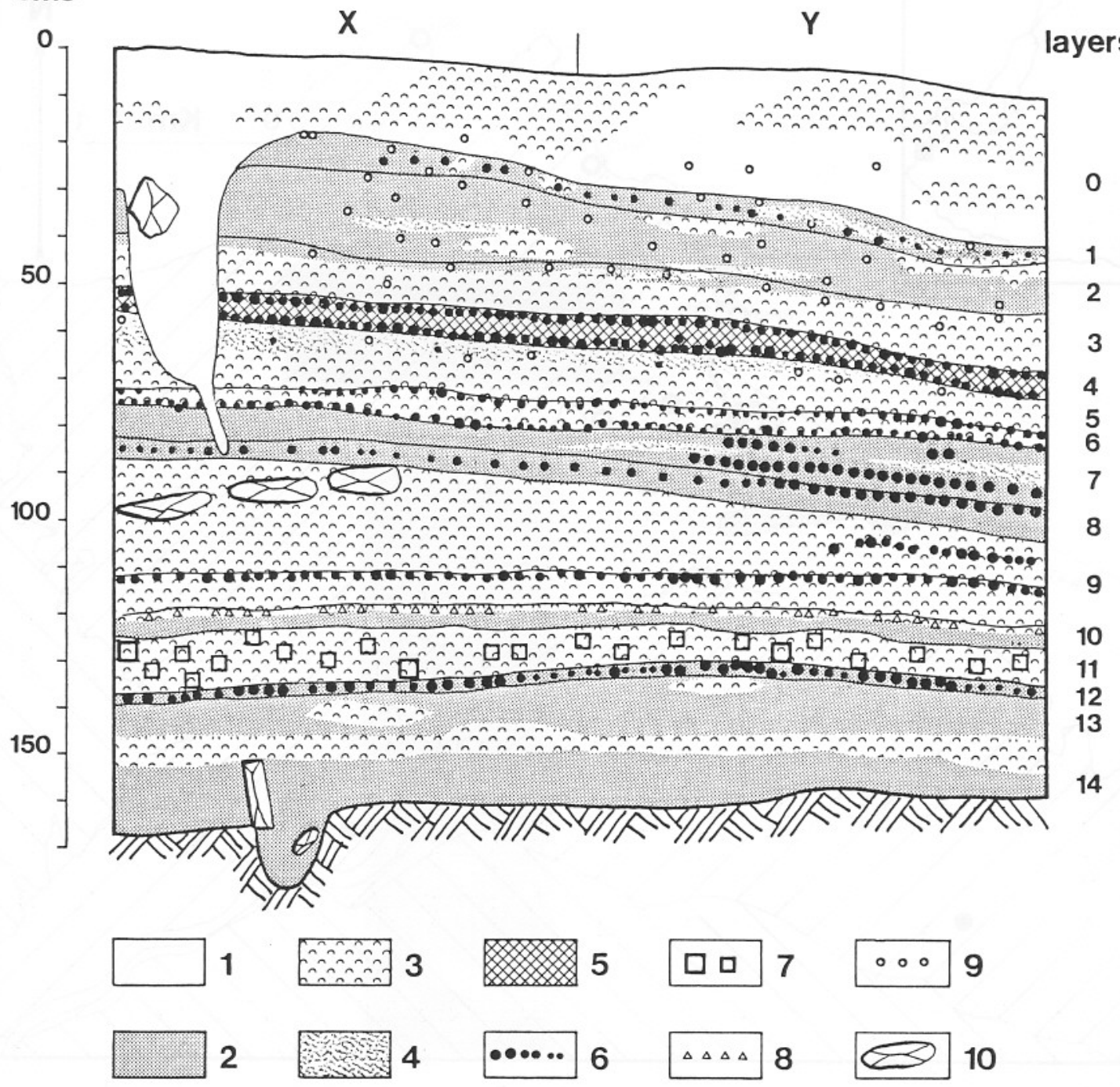

Fig. 2.

RH6. Section through the deposits of the western slope. 1) Disturbed layer. 2) Sand. 3) Shells. 4) Fish bones. 5) Ash. 6) Charcoal. 7) Coastal pebbles. 8) Beach gravel. 9) Concretions. 10) Stones (Drawn by P. Biagi).

evident traces of man-made features, such as post-holes, were recovered. The more recent aceramic layers were dated around the beginning of the sixth millennium BP. A double burial attributable to the Bronze Age, according to one radiocarbon date obtained from bone collagen, was found in the topmost layer (OxA-2629): 3580 \pm 80 BP: 2042 (1933) 1838 cal BC.
14C chronology of the other coastal sites (Table 4)

A few kilometres to the east of the Capital Area opens the bay of Bandar Khayran. During the coastal survey carried out in 1985, some shell-middens were discovered; others were recognized in 1990. These sites are characterized by scatters of Anadara uropigimelana (11) shells, among which lie a few stone arte- 
Table 4 (16)

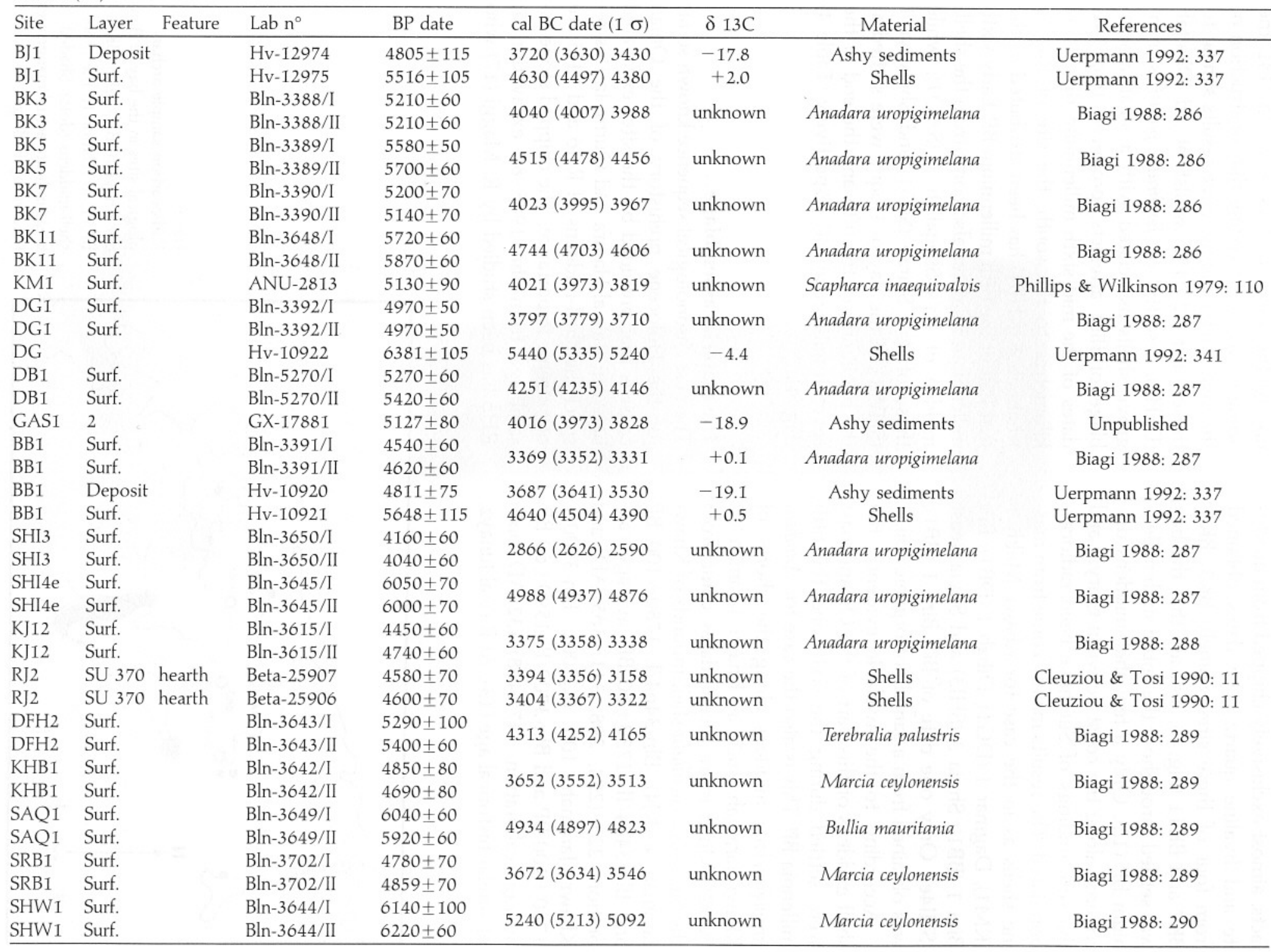


facts, almost exclusively chipped from quartzite and hyaline quartz. The dates obtained from four of these sites, namely BK $3, \mathrm{BK} 5$, BK7 and BKII (Fig. 3), indicate that the bay was settled throughout the entire sixth millennium BP (12). Only a few shell-middens discovered along the coast between Quryat and the surroundings of Sur have been radiocarbon dated. The results mainly come from marine shells as in the case for Khawr Milkh 1 (KM1), Dagmar I (DG1), Dibab I (DB1), Bi'r Bira I (BBI), Shyia 3 (SHI3) and Shyia 4east (SHI4e). Only one date of Bi'r Bira I (BBI), was obtained from a sample of organic soil.

According to the available evidence, the shell-middens of this part of the Omani coast were settled during the sixth and the fifth millennia BP. This is also the case for Anadara uropigimelana middens along the shores of Khawr Jaramah, such as Khawr Jaramah 12 (KJ12). Much more recent dates come from the Saccostrea cucullata shell-mounds of Khawr

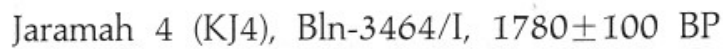
and Bln-3464/II, $1730 \pm 60 \mathrm{BP}$ : average calibration: $225(254,298,311) 365 \mathrm{AD}$, and Khawr Jaramah 100 (KJ100), Bln-3700/I, $1780 \pm 100 \mathrm{BP}$ and Bln-3700/II, $1590 \pm 60 \mathrm{BP}$ : average calibration: 347 (408) $432 \mathrm{AD}$, both of similar historical age (13). At Ra's al Junayz, just to the south of Ra's al Hadd (14), the aceramic layers, preceding the construction of the mud-brick building, gave results similar to those of KJ12 (15), whilst at ad Dhaffah (DFH2), a scatter of Terebralia palustris mangrove shells associated with a small assemblage of flint artefacts, produced two 14C dates of the mid sixth millennium BP. A few kilometres to the south, the site of Ra's al Khabbah I (KHBI) has been attributed to the first half of the fifth millennium BP. Early sixth millennium BP dates also come from the shellmidden of Ra's Shaqallah I (SAQ1); while those of Ra's Shirab (SRBI) and Shuwayr I (SHW1), in the Bay of Duqm, were settled at the beginning of the fifth and the end of the seventh millennium BP, respectively (Table 4) (Fig. 4).

\section{The material assemblage}

The best chronological sequence known so far for the Holocene prehistory of the Oman coast is that provided by the sites excavated between Ra's al-Hamra and Qurm. In this respect the shell-middens of RH6 and RH5 are of extreme importance. The chipped stone assemblage from the 1985-86 excavation at RH6 has been studied by R. Maggi (17) who

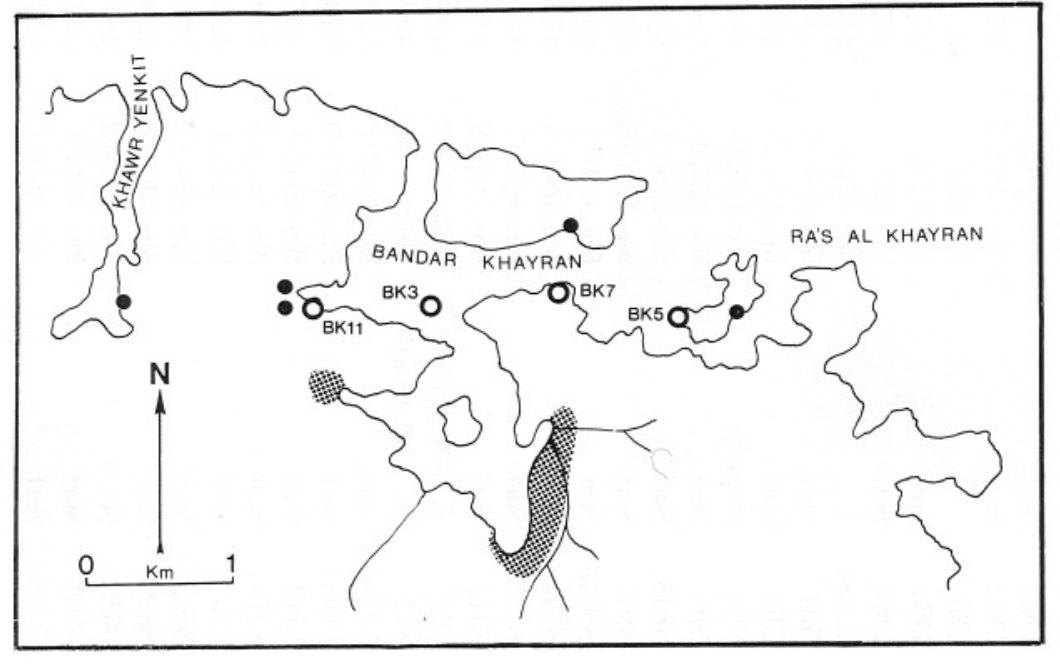

Fig. 3.

Radiocarbon sample archaeological sites in the bay of Bandar Khayran (BK3, BK5, BK7, BKII) in relation to the other shell-middens (dots). Shaded areas indicate actual mangroves (Drawn by P. Biagi). 
Fig. 4.

Radiocarbon sample archaeological sites along the coasts of Oman (circles) in relation to other shell-middens (dots) (Drawn by P. Biagi).

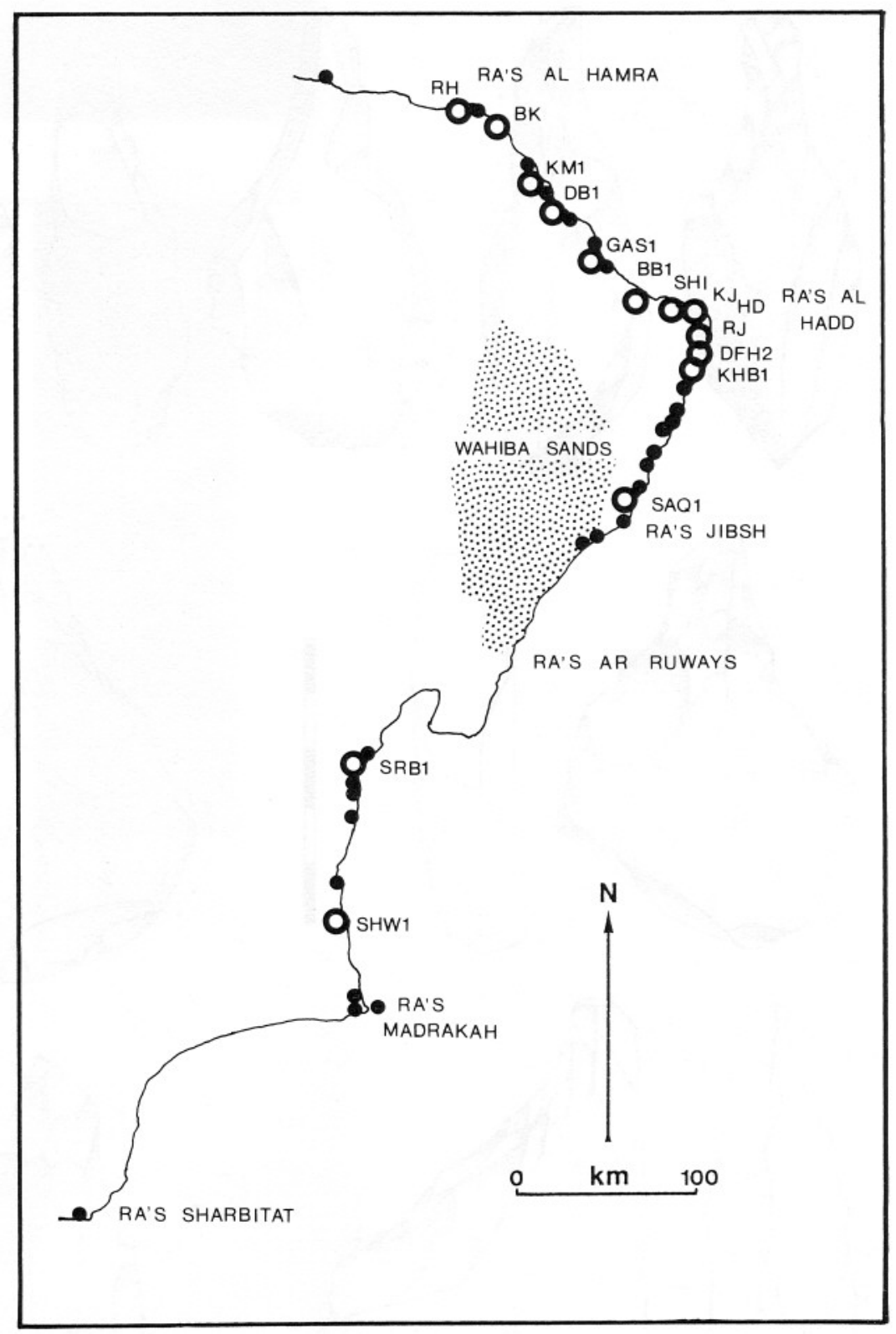

noted a strong variation in the raw material utilized throughout the centuries of occupation of the site. In particular, quartz artefacts are more represented in the lower layers, while those chipped from yellow flint are largely employed in the more recent horizons. This assemblage includes microlithic straight perforators, backed bladelets, end scrapers, side scrapers and rare flat retouched pieces, while "Ra's al-Hamra wedges" and pièces ésquillées, characteristic of the entire RH5 sequence (18), only appear with the final stages of settlement. These latter instruments are rather uncommon in the coastal Omani sites with the exception of those of Khor Milkh (KMI), Dibab (DBI) and Wadi Shab (GASI). 

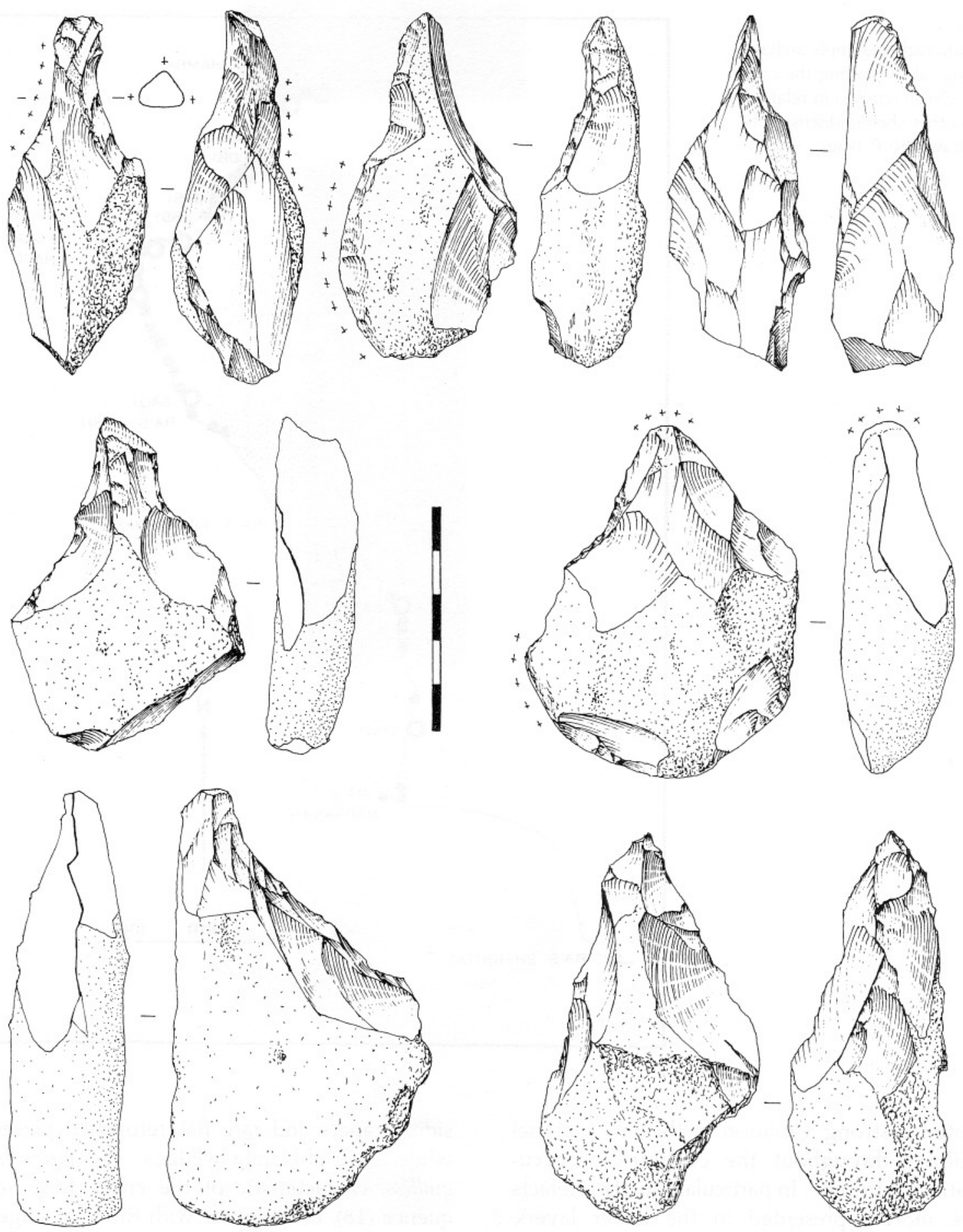

Fig. 5.

HD6. Bifacial thick points from surface (2:3) (Drawn by G. Almerigogna). 
The most accurate attempt at chronological seriation of the lithic industries of Oman is that of M. Uerpmann (19), mainly based on the results obtained from the Tübingen Archaeological Expedition and from the research carried out by $\mathrm{C}$. Edens and the writer along the southern coast (20). As regards the region surrounding the Capital Area, M. Uerpmann distinguishes five main facies of lithic industries spanning a period of some 7000 years. Even though many questions are still awaiting an answer, such as the moment of disappearance of flat retouched arrowheads like those collected at Ra's Shaqallah (SAQI) and dated from shells to $6040 \pm 60 \mathrm{BP}(\mathrm{Bln}-3549 / \mathrm{I})$ and $5920 \pm 60$ BP (Bln-3649/II): average calibration 4934 (4897) $4823 \mathrm{cal} \mathrm{BC}$, other problems are to be related to the activities carried out at the sites scattered over many hundred kilometres, sometimes lying in very different ecological zones as also reflected by differing species of shellfish visible on the surface. Specific instruments, which relate to well-defined activities such as the manufacture of pearl beads, are known from Wadi Shab (GAS1), dated to $5127 \pm 80 \mathrm{BP}$ (GX-17881). Other peculiar assemblages come from the site of Ra's al-Junayz 30 (RJ30), which has a very high proportion of long, straight perforators obtained from blades (21), very similar to those from the more inland site of Ra's al-Junayz 37 (RJ37) (22); and from Ra's al-Hadd 6 (HD6), a shell-mound which produced a great number of thick bifacial points chipped from pebbles (Fig. 5).

\section{Reservoir effects and radiocarbon age calibration}

Many of the $14 \mathrm{C}$ dates of the shell-middens of coastal Oman have been obtained from marine or mangrove shell samples (Fig. 6). Since no $\Delta \rho$ value is currently available for this part of the Indian Ocean (23), the calibration of the Omani samples has been an open question for several years. In a recent work H.-P. Uerpmann has suggested a correction of 800 years for the shell dates. This assumption is based on the comparison between the results obtained at three different sites from shell and ash samples collected from the same archaeological layer (24).

As mentioned above, the shell-middens of RH5 and RH6 have been accurately dated, also with the specific purpose of analyzing different materials from the same level and

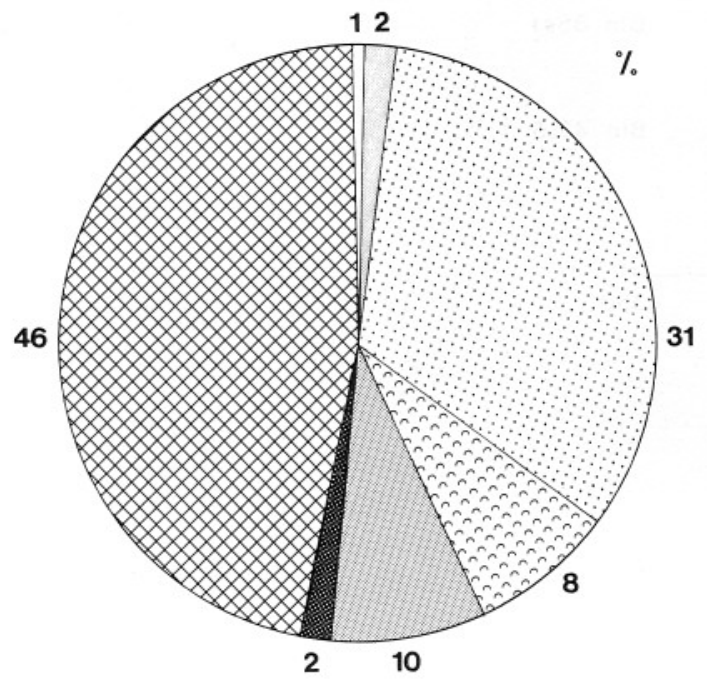

human bones

fish bones

marine shells

fir mangrove shells

ashy sediments

terrestrial plants

mangrove plants
Fig. 6.

Percentage diagram of the materials employed for the radiocarbon dating of the aceramic Omani shell-middens mentioned in the text (Drawn by P. Biagi). 
P. BIAGI

RJ1
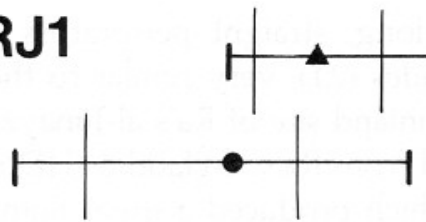

2000

1500

\section{RH5}
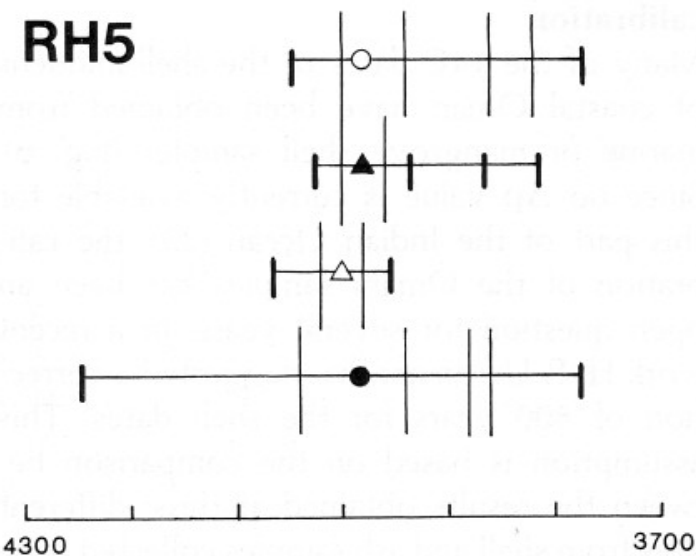

RH6

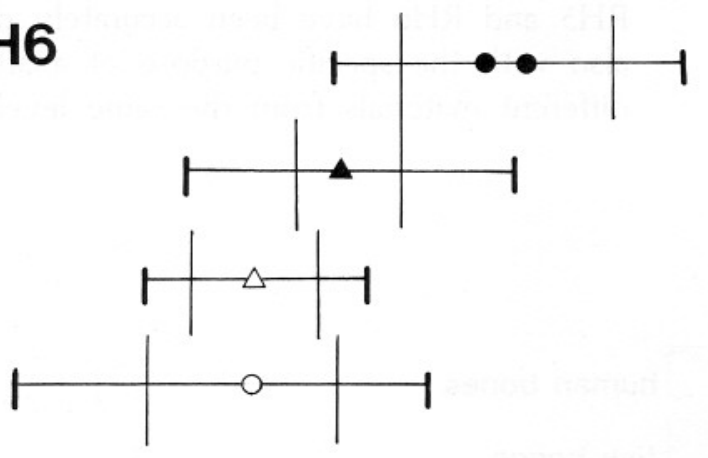

BIn 3652

BIn 3689
Fig. 7.

Calibrated $14 \mathrm{C}$ dates from RJ1 House 1 (above), RH5 layer 4 (centre) and RH6 layer 3 (below) (Drawn by P. Biagi).
BIn 3399

BIn 3394

BIn 3393

OxA 2931

BIn 4316

BIn 3640

BIn 3641

BIn 4315

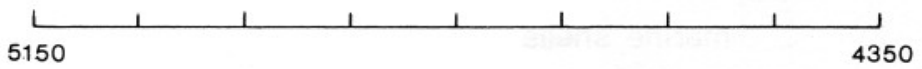

- TERRESTRIAL PLANTS

A MARINE SHELLS

1 SIGMA 
comparing the results. More precisely, experimental dates have been obtained from RH6, layer 3 (Table 3) and from RH5, layer 4 (Table $1)$. These results are very similar for RH6, where the charcoals of Ziziphus and other terrestrial plants are some 200 years younger than the specimens of marine shells, mangrove shells and charred wood. Almost identical dates come from RH5, from which marine shells, mangrove shells and charcoals and one seed of Setaria have been dated. As shown in Fig. 7 these results are also supported by those from House 5 at RJI (25).

\section{Considerations}

The evidence to date demonstrates that the coast of Oman has been inhabited since the second half of the seventh millennium BP. Sites of this age are known both from the excavations carried out at Qurm and from the discoveries made along the coast to the north (SHI4e) and to the south of Ra's al Hadd (SHWI).

According to the most recent data, the appearance of the shell-midden sites might correspond to the climatic deterioration that, following a long pluvial period, started around $6500 \mathrm{BP}$ and led, soon afterwards, to the current arid phase (26).

It is not easy to establish the provenance of these first communities of aceramic fishergatherers who settled along the coast of Oman. The search for better ecological zones such as those represented by the mouth of the wadis where mangrove swamps were already established, and where various environments could be exploited at the same time, might have played an important role. Earlier sites are not known in this territory, with the exception of that of Wadi Wutayya (WW), some three kilometres inland, along the right bank of Wadi Aday. The oldest of the sequence of dates from this site come from ash samples from two overimposed fire-places that were quoted to $9445 \pm 65 \mathrm{BP}$ (Hv-12964), out of the calibration range, and $7183 \pm 85 \mathrm{BP}(\mathrm{Hv}-$ 12963): 6117 (6034) 5976 cal BC yrs. Unfortunately the chipped stone industry from these levels is composed of a restricted number of tools. The upper layer 4 gave two dates, from ash and shells, respectively: $5698 \pm 100 \mathrm{BP}$ : 4710 (4544) $4460 \mathrm{Cal} \mathrm{BC}$ (Hv-12965), and $6342 \pm 60$ BP: 5350 (5312) $5237 \mathrm{Cal} \mathrm{BC} \mathrm{(Hv-}$ 12967) (27). They fit well into the range of those obtained from the shell-middens of the cape of Ra's al Hamra. The oldest sites of this area are those of RH6, RH7 and RH10, but, while RH6 was almost uninterruptedly settled for at least 800 years, the occupations of RH7 and RH10 seem to have been more episodic. Strong differences are to be noted also as regards the site locations. RH6 lies on the right mouth of Wadi Aday. Its margins are only seven metres above the highest level reached by the maximum tide (28). RH7 and RH10, in contrast, are located on the Tertiary terrace that was later settled for some 700 years by the RH5 communities. A great number of aceramic shell-middens seem to have been inhabited during the sixth and the fifth millennia $\mathrm{BP}$, a period with coastal environment and climatic conditions almost identical to the present ones.

\section{Acknowledgements}

The Author is very grateful to Dott Ali Ahmed Bakhit al-Shanfari, Director of Antiquities of the Sultanate of Oman, and to Prof. M. Tosi, former Director of the Italian Archaeological Expedition to the Sultanate of Oman, for all their help and support. Special thanks are due to Drs H. Quitta, K. Rassmann and J. Görsdorf, of the $14 \mathrm{C}$ Laboratory of Berlin (D), for providing many of the dates shown in this article, as well as to Prof. M. A. Geyh, of the 14C Laboratory of Hanover (D), for all the information on the Hv-results. The original English text was revised by Dr Barbara A. Voytek of the University of California, Berkeley.

\section{References}

1. Tosi M \& Durante S. The aceramic shell middens of Ra's al-Hamra: a preliminary note. JOS 3 (2): 1977: 162. 
2. Biagi P, Torke W, Tosi M \& Uerpmann H-P. Qurum: a case study of coastal archaeology in Northern Oman. World Archaeology 16 (1): 1984: 57.

3. Biagi P. Surveys along the Oman coast: preliminary report on the 1985-1988 campaigns. EW 38 (1-4): 1988: 271-291.

4. Biagi P \& Nisbet R. Some aspects of the 1982-1985 excavations at the aceramic coastal settlement of RH5 at Qurm (Muscat - Sultanate of Oman). In: Costa PM \& Tosi M, eds. Oman Studies. Rome: Serie Orientale Romana 63: 1989: 31-46.

5. Cleuziou S \& Tosi M. The southern frontier of the ancient Near East. In: Frifelt K \& Sørensen P, eds. South Asian Archaeology 1985, London: Curzon, 1989: 28. On pages 29-31 of this article this feature is mistakenly called Pit HWD and in Table $I$ is inexplicably attributed to $\mathrm{ca} .3200-3100 \mathrm{cal} \mathrm{BC}$ yrs.

6. Throughout the text, BP refers to uncalibrated dates; $B C$ and $A D$ are used to indicate calibrated radiocarbon dates.

7. Biagi P \& Salvatori S. Gli scavi nell'Insediamento preistorico e nella necropoli di Ra's al-Hamra 5 (Sultanato dell'Oman). Rivista di Archeologia 10: 1986: 5-14.

8. Santini G. Site RH10 at Qurum and preliminary analysis of its cemetery. PSAS 17: 1987: 179-198.

9. Biagi P. Excavation of the aceramic shell midden of RH6, Qurm, Muscat. EW 35 (4): 1985: 410-415.

10. Biagi P \& Nisbet R. Environmental history and plant exploitation at the aceramic sites of RH5 and RH6 near the mangrove swamp of Qurm (Muscat Oman). In: Vernet J-L, ed, Les charbons de bois, les anciens ecosystemes et le role de l'homme: 1992. Bulletin de la Societé Botanique de France 139: in press.

11. Identified by Dr L. Mizzan of the Natural History Museum of Venice (Italy).

12. Two more dates are reported by Uerpmann H-P for the same unspecified site of Bandar Khayran. They are Hv-10923: $1370 \pm 50 \mathrm{BP}: 633$ (655) $676 \mathrm{cal} \mathrm{AD}$

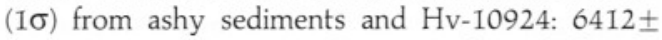
105: 5470 (5353) 5250 cal BC ( $1 \sigma)$ from shells. See Uerpmann H-P. Radiocarbon dating of shell middens in the Sultanate of Oman. PACT 29: 1992: 337.

13. Biagi, Surveys along the Oman coast: 288 .

14. A set of first-order radiocarbon dates has been obtained from shells recovered from HD1 at Ra's alHadd. (UCL-109) 4300 \pm 200 BP: 3307 (2915) 2619 cal BC, was obtained from the uppermost levels containing imported Harappan pottery; while the lower levels that yielded only one sherd of locallymade pottery gave the results of (UCL-108) 4900 \pm 300 BP: 4030 (3708) $3380 \mathrm{cal} \mathrm{BC}$ and (UCL-122) $5600 \pm 500$ BP: $5040(4460) 3920 \mathrm{cal} \mathrm{BC}$ yrs. One sample of marine shells collected from the surface from the nearby aceramic shell-midden of HD2, da- ted with the same method, gave the result of $6100 \pm$ 300 BP: 5350 (5036) 4690 cal BC yrs (UCL-125). See Glover E, Glover I \& Vita-Finzi C. First order $14 \mathrm{C}$ dating of marine molluscs in archaeology. Antiquity 64 (244): 1990: 562-567; Reade J. Excavations at Ra's al-Hadd, 1988: Preliminary report. The Joint Hadd Project. Summary Report on the Third Season. October 1987-February 1988: 1990: 33-43.

15. Cleuziou S \& Tosi M. The third campaign at RJ-2. A preliminary report. The Joint Hadd Project. Summary Report on the Third Season. October 1987-February 1988: 1990: 11-27.

16. The following references are reported from Table 1 to Table 4: Isetti E \& Biagi P. The polished stone earrings of Site RH5 and the distribution and chronology of the prehistoric earrings of coastal Oman. Rivista di Archeologia 13: 1989: 6; Biagi P \& Nisbet $\mathrm{R}$. The shell midden sites of RH5 and RH6 in their environmental setting. Beheifte des Tübinger Atlas des Vorderen Orients in press; Biagi \& Nisbet, Environmental history and plant exploitation; Uerpmann $\mathrm{H}$ P, Radiocarbon dating of shell middens: 335-347; Biagi P, Torke W, Tosi M \& Uerpmann H-P, Qurum: a case study of coastal archaeology in Northern Oman: 57; Meulengracht A, McGovern P \& Lawn B. University of Pennsylvania radiocarbon dates XXI. Radiocarbon 23 (2): 1981: 232-233; Biagi, Surveys along the Oman coast: 286-290; Phillips CS \& Wilkinson TJ. Recently discovered shell middens near Quriyat. JOS 5: 1979: 110; Cleuziou \& Tosi, The third campaign at RJ-2: 11 .

In this article also the dates obtained from shells at $\mathrm{Hv}$ - laboratory are shown without $\delta 13 \mathrm{C}$ normalization. This is why the results differ from those displayed by H-P Uerpmann, Radiocarbon dating of shell middens: 341 of 164 (Hv-10922) -351 (Hv14212) years (Geyh, in litteris. 9. 5. 1992 and 13. 7. 1992).

17. Maggi R. The chipped flint assemblage of RH6 (Muscat, Sultanate of Oman). Some consideration on technological aspects. EW 40 (1-4): 1990: 293-300.

18. Maggi R \& Gebel H-G. A preliminary report on the chipped stone industries of the Mid-Holocene shellmidden communities of Ra's al-Hamra 5, Layer 1 (Muscat, Sultanate of Oman). Rivista di Archeologia 14: 1990: 5-23. For the significance of the term "Ra's al-Hamra wedge", see Uerpmann M. Structuring the Late Stone Age of Southeastern Arabia. AAE 3: 1992: 78-79.

19. Uerpmann M. Abschlußbericht über die Wissenschaftlichen Ergebnisse der Untersuchung von Silexartefakten der Späten Steinzeit aus dem Sultanat Oman (SO-Arabien). Institut für Urgeschichte Universität Tübingen: 1988: unpublished manuscript; 
Uerpmann M, Structuring the Late Stone Age: 65-109.

20. Edens C. Archaeology of the sands and adjacent portions of the Sharqiyah. JOS Special Report 3: 1988: 113-130. Biagi, Surveys along the Oman coast: 271-291.

21. Biagi P \& Maggi R. Prehistoric surveys carried out in the winter of 1986/1987 along the Oman coast. The Joint Hadd Project. Summary Report on the Second Season. November 1986-January 1987: 1987: 61.

22. Charpentier V. La fouille du campement préhistorique de Ra's al Junayz 37, (RJ37) - Sultanat d'Oman. Paléorient 17 (1): 1991: 136.

23. Stuiver M, Pearson GW \& Braziunas TF. Radiocarbon age calibration of marine samples back to 9000 Cal Yr BP. Radiocarbon 28 (2B): 1986: 980-1021.

24. Uerpmann H-P, Radiocarbon dating of shell middens: 337 .

25. It is very important to bear in mind that all the $14 \mathrm{C}$ dates shown in this article are not $\delta 13 \mathrm{C}$ normalized and that OxA-2931 has a $\delta 13 \mathrm{C}$ of -26.9 .
26. Clark ID \& Fontes J-C. Paleoclimatic reconstruction in Northern Oman based on carbonates from hyperalkaline groundwaters. Quaternary Research 33: 1990: 320-336.

27. Uerpmann M. Some remarks on the Late Stone Age industries from the coastal area of Northern Oman. In: Costa P \& Tosi M, eds, Oman Studies, Rome: Serie Orientale Romana, 63: 1989: 169-177; Uerpmann M, Structuring the Late Stone Age: 65-109.

28. Biagi, Excavation of the aceramic shell midden of RH6: 410-415.

Address:

Paolo Biagi

Dipartimento di Scienze Storico-Archeologiche e Orientalistiche

Università di Venezia

Palazzo Bernardo. S. Polo 1977A

I-30125 Venice, Italy 